\title{
Article \\ A Luminescent, Water-Soluble Ir(III) Complex as a Potential Photosensitizer for Two-Photon Photodynamic Therapy
}

\author{
Elisabeta I. Szerb ${ }^{1}\left(\mathbb{D}\right.$, Sharmistha Chatterjee ${ }^{2}\left(\mathbb{C}\right.$, Massimo La Deda $\left.^{3,4}{ }^{(}\right)$, Giovanna Palermo ${ }^{2}$, Lucie Sancey ${ }^{5}(\mathbb{D}$, \\ Giuseppe Strangi ${ }^{2,4,6}$ and Loredana Ricciardi ${ }^{4, *}$ (D) \\ 1 Coriolan Dragulescu, Institute of Chemistry, Romanian Academy, 24 Mihai Viteazu Bvd., \\ 300223 Timisoara, Romania; szella73@gmail.com \\ 2 Department of Physics, University of Calabria, 87036 Rende, Italy; chatterjee.bwd@gmail.com (S.C.); \\ giovanna.palermo@unical.it (G.P.); gxs284@case.edu (G.S.) \\ 3 Department of Chemistry and Chemical Technologies, University of Calabria, 87036 Rende, Italy; \\ massimo.ladeda@unical.it \\ 4 CNR NANOTEC-Institute of Nanotechnology U.O.S. Cosenza, 87036 Rende, Italy \\ 5 Institute for Advanced Biosciences INSERM U1209, CNRS UMR5309 UGA, Allée des Alpes-Site Santé, \\ 38700 La Tronche, France; lucie.sancey@univ-grenoble-alpes.fr \\ 6 Department of Physics and Case Comprehensive Cancer Center, Case Western Reserve University, \\ 10600 Euclid Avenue, Cleveland, OH 44106, USA \\ * Correspondence: loredana.ricciardi@cnr.it
}

\section{check for} updates

Citation: Szerb, E.I.; Chatterjee, S.; La Deda, M.; Palermo, G.; Sancey, L.; Strangi, G.; Ricciardi, L. A Luminescent, Water-Soluble Ir(III) Complex as a Potential Photosensitizer for Two-Photon Photodynamic Therapy. Appl. Sci. 2021, 11, 11596. https://doi.org/ 10.3390/app112411596

Academic Editor: David García Fresnadillo

Received: 25 October 2021

Accepted: 3 December 2021

Published: 7 December 2021

Publisher's Note: MDPI stays neutral with regard to jurisdictional claims in published maps and institutional affiliations.

Copyright: (c) 2021 by the authors. Licensee MDPI, Basel, Switzerland. This article is an open access article distributed under the terms and conditions of the Creative Commons Attribution (CC BY) license (https:// creativecommons.org/licenses/by/ $4.0 /)$.
Abstract: This work reports the study of two-photon induced properties of a highly luminescent cyclometalated $\operatorname{Ir}(\mathrm{III})$ complex, $\left[\operatorname{Ir}(\mathrm{ppy})_{2}(\mathrm{en})\right] \mathrm{OOCCH}_{3}(\mathbf{1})$, ppy = 2-phenylpyridine, en = ethylenediamine. Steady-state and time-resolved fluorescence measurements were performed by exciting $\mathbf{1}$ at the biologically relevant wavelength of $800 \mathrm{~nm}$, whereas, the generation of singlet oxygen $\left({ }^{1} \mathrm{O}_{2}\right)$ was evaluated using 9,10-Anthracenediyl-bis(methylene)dimalonic acid (ABDA) as a detection probe. Preliminary in vitro experiments with U87-MG cells were performed, showing the potential of this compound as a two-photon photodynamic therapy (2P-PDT) agent at NIR wavelengths.

Keywords: cyclometalated $\operatorname{Ir}(\mathrm{III})$ complexes; two-photon photodynamic therapy; time-resolved luminescence spectroscopy

\section{Introduction}

Photodynamic therapy (PDT) is a minimally invasive clinical approach approved for the treatment of numerous cancers [1] and non-cancerous diseases, which include psoriasis [2,3], age-related macular degeneration [4], viral [5,6] and fungal [7] infections. It requires the simultaneous presence of three key components: a photosensitizer (PS), a light source and molecular oxygen. After light activation, PS transfers the absorbed energy to the surrounding molecular oxygen generating singlet oxygen $\left({ }^{1} \mathrm{O}_{2}\right)$, a highly reactive species able to cause oxidative damage to proteins, lipids and nucleic acids sited in its proximity, consequently leading to cell death [8].

However, most current PSs used for PDT applications are activated by wavelengths in the UV-Vis range [9], which cannot efficiently penetrate into the biological tissue, strongly hindering the use of PDT for the treatment of deep-seated diseases. To overcome this drawback more attention has recently focused on "deep PDT techniques" [10]—such as two-photon photodynamic therapy (2P-PDT) - which involves the use of two-photon absorbing PSs that are triggered by excitation wavelengths in the spectral NIR region [11,12]. Compared with linear UV-Vis excitation, two-photon excitation allows a higher spatial resolution [13] and a greater penetration depth into living tissues [14].

The key difference between 2PE-PDT and traditional PDT is the light absorption mechanism, while their other photophysical and photochemical processes are analogous [12]. In two-photon excitation, absorption of two photons of NIR wavelengths leads to the same 
excited state of the PS typically populated by the absorption of one photon of around twice the energy. The efficiency of two-photon absorption (2PA) can be identified as the 2PA cross-section $\left(\sigma_{2}\right)$ of the PS, which is similar to the molar absorption coefficient in a one-photon absorption process.

The first successful in vivo PDT experiment using a PS engineered for efficient twophoton excitation was reported by Anderson and co-workers in 2008 [15]. The authors synthesized a new conjugated porphyrin dimer and demonstrated-after injection, followed by two-photon irradiation at $920 \mathrm{~nm}$ - the selective closure of blood vessels in mice bearing skinfold window chambers [15].

Over the last few decades, transition metal complexes have attracted a growing interest as PSs and imaging probes for theranostic applications [16] and, more recently, as promising multi-photon absorbing materials [17-19].

In particular, the presence of a heavy atom, favoring the intersystem crossing process, leads to the population of excited triplet states, usually metal-to-ligand charge transfer (MLCT) excited states. Since these states have a distorted symmetry with respect to that of the ground state, the radiative deactivation is disadvantaged, whereas an energy transfer process towards molecular oxygen is favored, with consequent singlet oxygen generation.

Furthermore, the metal center can act as multidimensional scaffold assembling several two-photon active ligands in a variety of arrangements and, depending on the nature of the metal-promoting long-range intramolecular charge transfer processes, which are known to be crucial for improving nonlinear optical properties [20]. Hence, transition metal complexes that exhibit ILCT (intraligand charge transfer) and MLCT transitions, i.e., $\mathrm{Ru}(\mathrm{II})$ and Ir(III) compounds, turn out to be promising candidates for two-photon applications [21,22]

In 2009, Lemercier's group reported the first example of in vitro 2P-PDT studies using a water soluble $\mathrm{Ru}$ (II) complex [23] as a photosensitizer. A few years later, Nam and colleagues synthesized and evaluated in vitro the first $\operatorname{Ir}(\mathrm{III})$-based molecular dyad as a two-photon singlet oxygen generation agent and fluorescent probe [24]. Since then, a number of luminescent $\mathrm{Ru}$ (II) and Ir(III) complexes with two-photon absorption behavior have been developed for application in bioimaging and cancer phototherapy [11,25-32].

Previously, we reported the synthesis and characterization of the cyclometalated $\operatorname{Ir}(\mathrm{III}) \mathrm{com}$ plex [ $\left.\operatorname{Ir}(\mathrm{ppy})_{2}(\mathrm{en})\right] \mathrm{OOCCH}_{3},(\mathbf{1})$, where ppy = 2-phenylpyridine and en = ethylenediamine [33] (Figure 1). The presence of a hydrophilic acetate as counterion induces a high water solubility $(45 \mathrm{mg} / \mathrm{mL})$, making the organometallic compound very appealing for biological applications.<smiles></smiles>

(1)

Figure 1. Chemical structure of $\left[\operatorname{Ir}(\mathrm{ppy})_{2}(\mathrm{en})\right] \mathrm{OOCCH}_{3}$ compound (1).

Upon one-photon excitation, 1 displayed remarkably high phosphorescence quantum yield and oxygen photosensitizing ability $[33,34]$. Thus, based on the interesting photophysical properties, it was investigated in vitro and in vivo as a PS and lumines- 
cent probe, showing it could fully satisfy the requirements of a potential theranostic anticancer agent [34,35].

Herein, in order to extend the bio-applicability of the compound within the therapeutic window, $\sigma_{2}$ value at $800 \mathrm{~nm}$ was determined and the two-photon induced properties were assessed. In particular, steady-state and time-resolved photoluminescence, as well as singlet oxygen generation ability, were explored. Then, its effectiveness as a 2P-PDT therapeutic agent was evaluated by preliminary in vitro tests with U87-MG cells.

\section{Materials and Methods}

Compound 1 was prepared according to our previously reported procedure [33].

Two-photon steady-state and time-resolved photoluminescence measurements were performed by means of an Edinburgh Instruments' FLS 980 fluorometer using a pulsed Ti-sapphire laser (repetition rate $=80 \mathrm{MHz}$, pulse width $=140 \mathrm{fs}$, by Coherent Inc., Santa Clara, CA, USA) as excitation source. In order to synchronize the spectrofluorometer with the Ti:Sa pulses, a pulse picker was used to decrease the repetition rate from $80 \mathrm{MHz}$ to $4 \mathrm{MHz}$.

Two-photon absorption cross section $\left(\sigma_{2}\right)$ at $800 \mathrm{~nm}$ was calculated by using a Rhodamine $\mathrm{B}$ methanol solution as reference [36], through the following equation:

$$
\sigma_{2(\text { sample })}=\sigma_{2(\text { reference })} \cdot \frac{\Phi_{(\text {reference })}}{\Phi_{(\text {sample })}} \cdot \frac{C_{(\text {reference })}}{C_{(\text {sample })}} \cdot \frac{I_{(\text {sample })}}{I_{(\text {reference })}} \cdot \frac{n_{(\text {sample })}}{n_{(\text {reference })}}
$$

where $\Phi$ is the luminescence quantum yield, $C$ is the concentration, $I$ is the integrated luminescence intensity and $n$ is the refractive index.

Two-photon-induced singlet oxygen generation was monitored by chemical oxidation of 9,10-Anthracenediyl-bis(methylene)dimalonic acid (ABDA) (Sigma-Aldrich, St. Louis, Missouri, MO, USA) in aqueous solution [37]. A volume of $15 \mu \mathrm{L}$ of ABDA solution $\left(2 \mathrm{mg} / \mathrm{mL}\right.$ DMSO) was mixed with $300 \mu \mathrm{L}$ of $\mathbf{1}$ water solution $\left(8 \cdot 10^{-5} \mathrm{M}\right)$ and placed in a quartz cuvette with an optical path length of $0.1 \mathrm{~cm}$. The absorption spectra were recorded upon irradiation at $800 \mathrm{~nm}$ for $15 \mathrm{~min}\left(100 \mathrm{~mW} / \mathrm{cm}^{2}\right)$ at 3 min intervals. For comparative purposes, a similar ABDA solution was dispersed in water and irradiated under the same conditions. Then, monitoring the ABDA absorbance as a function of number of moles present in solution [35], it was calculated the amount of reacted ABDA molecules, and conversely of ${ }^{1} \mathrm{O}_{2}$, after a total irradiation time of $15 \mathrm{~min}$. Absorption spectra were recorded using a Cary $300 \mathrm{UV}-\mathrm{Vis}$ spectrophotometer. To exclude any possible ABDA spectral variation due to photoactivated redox processes triggered by $\mathbf{1}$, absorption spectra of ABDA in presence of $\mathbf{1}$ in aerated and deaerated water solution were collected, detecting no significant spectral variation of the probe in absence of molecular oxygen.

Calcein-AM staining assay was performed on U87-MG cells (human glioblastoma cells). The cells were cultured with DMEM containing $10 \%$ FBS. One day before the experiment, the cells were plated into LabTek Chamber I. For the experiment, cells were incubated with a medium containing $10 \mu \mathrm{M}$ of compound 1 for $1 \mathrm{~h}$. Then, calcein-acetyoxymethyl (calcein-AM) was added at $2 \mu \mathrm{M}$. The region of interest (ROI) was scanned 10 times using an $800 \mathrm{~nm}$, two-photon laser, at $100 \%$ power intensity $(39 \mathrm{~mW})$. After photo exposure, the fluorescence was collected in the ROI and at distance from the ROI using different excitation/emission wavelengths: compound 1 was excited at two-photon $800 \mathrm{~nm}$, emission $535-590 \mathrm{~nm}$; calcein was excited at $488 \mathrm{~nm}$, emission 500-550 nm.

\section{Results and Discussion}

\subsection{Two-Photon-Induced Luminescence}

We previously reported and extensively discussed the absorption spectrum of $\mathbf{1}$ in different solvents [33] and for a better visualization, the absorption profile in aqueous solution is displayed in Figure 2a. The compound intensely absorbed in the UV region (250-300 nm), with weaker bands in the visible (390-450 nm), and shoulders between 460 and $480 \mathrm{~nm}$ due to a direct, spin-forbidden population of the triplet-excited states 
( ${ }^{3} \mathrm{MLCT}$ and ${ }^{3} \mathrm{LC}$ mixed transitions). Under one-photon excitation at $400 \mathrm{~nm}, \mathbf{1}$ exhibited a strong luminescence in the range $470-620 \mathrm{~nm}$ (Figure 2a); the emission quantum yield in air-equilibrated and deaerated aqueous solution was 0.1 and 0.96 , respectively, with lifetimes on the time scale of hundreds of nanoseconds ( $395 \mathrm{~ns}$ in air-equilibrated water) to microseconds ( $2.37 \mu \mathrm{s}$ in deaerated water) $[32,36]$. The long lifetime values confirmed the triplet nature of the emissive state. The significant quenching effect on the luminescence quantum yield and lifetime in the air-equilibrated condition confirmed that molecular oxygen in its ground state was able to interact with the triplet excited state of $\mathbf{1}$, highlighting, indirectly, the huge photosensitizing abilities of the organometallic compound.

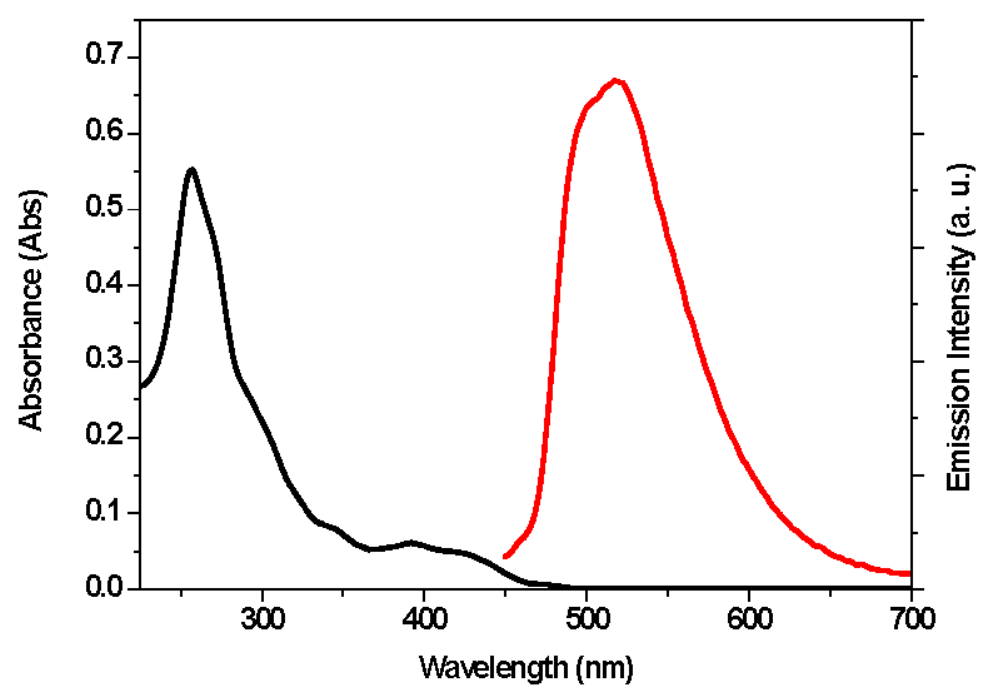

(a)



(b)

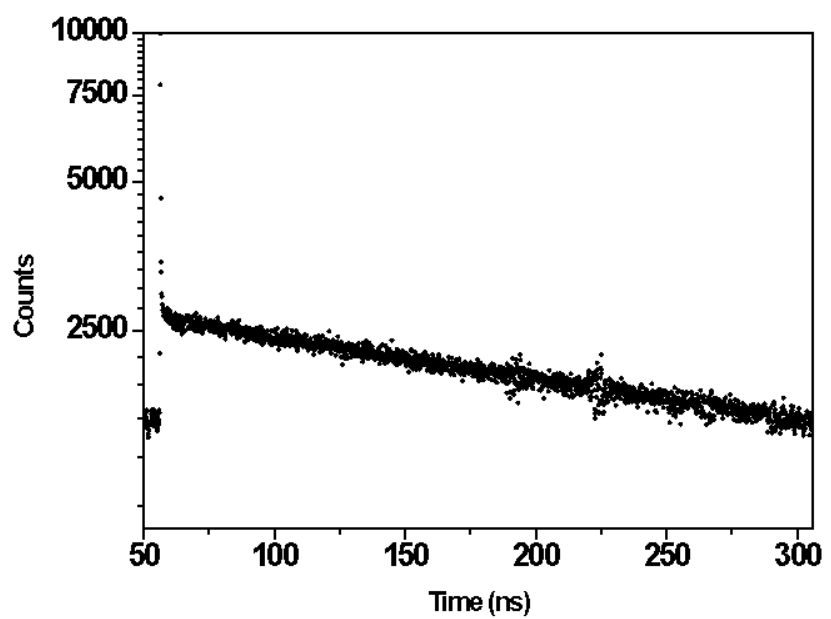

(c)

Figure 2. (a) Absorption and emission spectra of $\mathbf{1}$ in water solution $\left(2 \cdot 10^{-5} \mathrm{M}\right)$. The emission spectrum was acquired under one-photon excitation at $400 \mathrm{~nm}$. (b) Emission spectrum and (c) time-resolved fluorescence decay of 1 in water solution $\left(1.54 \cdot 10^{-2} \mathrm{M}\right)$ under two-photon excitation at $800 \mathrm{~nm}$. The used fitting equation was $\mathrm{I}(\mathrm{t})=\mathrm{I}_{0}+\alpha_{1} \exp \left(-\mathrm{t} / \tau_{1}\right)+\alpha_{2} \exp$ $\left(\mathrm{t} / \tau_{2}\right)$, with $\mathrm{I}_{0}=621.51, \alpha_{1}(\%)=32, \alpha_{2}(\%)=68, \tau_{1}=0.21 \mathrm{~ns}, \tau_{2}=388.4 \mathrm{~ns}$ and a $\chi^{2}=0.973$.

The two-photon-induced luminescence properties of $\mathbf{1}$ were investigated in air-equilibrated aqueous solution by using a femtosecond $\mathrm{Ti}$ /sapphire laser as excitation source. As shown 
in Figure $2 b$, the obtained emission profile, upon two-photon excitation at $800 \mathrm{~nm}$, was similar in shape and energy to that of the linearly-excited emission (Figure 2a), indicating that the same excited state was reached by either one or two-photon excitation. Then, the fluorescence lifetime of 1 was obtained using a time-correlated, single-photon counting technique. The resulting decay curve shown in Figure $2 c$, exhibits a bi-exponential behavior consisting of a slow component (388 ns) - which dominates the decay profile-and a very fast component $(0.21 \mathrm{~ns})$ with a relative intensity of $32 \%$. The lifetime value of the long component was identical (within experimental error) to that reported by exciting the sample under one-photon excitation at $400 \mathrm{~nm}$ (395 ns), and was ascribed to the phosphorescence arising from the excited ${ }^{3}$ MLCT state. Regarding instead the fast component, in agreement with what was observed for the parent complex $\operatorname{Ir}(\mathrm{ppy})_{3}$ under two-photon excitation [38], it could be attributed to a fluorescence from the ${ }^{1}$ MLCT state populated by internal conversion from higher energy states, reached by two-photon absorption processes.

To investigate the 2PA properties of 1 in water, the 2PA cross section at $800 \mathrm{~nm}$ was determined by the two-photon excited fluorescence (TPEF) technique [14], using Rhodamine $\mathrm{B}$ as standard. The measured $\sigma_{2}$ value of 1 was $3.5 \mathrm{GM}\left(1 \mathrm{GM}=10^{-50} \mathrm{~cm}^{4} \mathrm{~s}_{\text {photon }}^{-1}\right)$. As suggested by Furuta et al., $\sigma_{2}$ values should be higher than $0.1 \mathrm{GM}$ for optical imaging applications in live specimens [39]. The $\sigma_{2}$ value of $\mathbf{1}$ not only met the requirement mentioned above but it was higher than that of the clinical photosensitizer $\mathrm{H}_{2} \mathrm{TPP}\left(\sigma_{2}=2.2 \mathrm{GM}\right.$ at $800 \mathrm{~nm}$ in chloroform solution) [40]. However, this value was lower than those of relative Ir(III) complexes bearing the same cyclometalated ligand (2-phenylpyridine) and extended $\pi$-conjugate diamine $\left(\mathrm{N}^{\wedge} \mathrm{N}\right)$ ligands, such as a 5-fluorene-1,10-phenanthroline fragment ( $\sigma_{2}=10 \mathrm{GM}$ at $800 \mathrm{~nm}$ in degassed acetonitrile solution) [26], terpyridine fragments $\left(\sigma_{2}=50-80 \mathrm{GM}\right.$ at $800 \mathrm{~nm}$ in dichloromethane solution) [41] or (E)-2-styryl-1H-imidazo [4,5f] $[1,10]$ phenanthroline fragments $\left(\sigma_{2}=113-168 \mathrm{GM}\right.$ at $800 \mathrm{~nm}$ in methanol solution) [27].

\subsection{Two-Photon-Induced Singlet Oxygen Generation}

To gain insight in the potential of $\mathbf{1}$ as PS in $2 \mathrm{P}-\mathrm{PDT}$, the efficiency of ${ }^{1} \mathrm{O}_{2}$ generation was measured by monitoring the time-dependent absorbance of ABDA, a specific probe for the detection of ${ }^{1} \mathrm{O}_{2}$ [42]. In particular, ABDA reacted irreversibly with an ${ }^{1} \mathrm{O}_{2}$ molecule which led to the corresponding endoperoxide resulting in the decrease in its optical density at $378 \mathrm{~nm}$.

Figure $3 \mathrm{a}, \mathrm{b}$ shows the absorption spectra of ABDA in aqueous solution (control) and in presence of $\mathbf{1}$ at different irradiation times (0-15 $\mathrm{min})$, respectively. Although for the control sample no change in the ABDA absorbance was observed. In presence of 1 the ABDA absorption peaks decreased in intensity as the exposure time increased, highlighting the ${ }^{1} \mathrm{O}_{2}$ generation ability of the $\mathrm{Ir}(\mathrm{III})$ complex on two-photon excitation. For an intuitive comparison, the values of the ABDA absorbance as a function of the irradiation time were plotted in Figure $3 c$, displaying a good linear relationship. Then, ${ }^{1} \mathrm{O}_{2}$ generation was quantitatively estimated calculating the total number of moles produced upon photoirradiation, obtaining a value of $6 \cdot 2 \cdot 10^{-9}$ (Table 1 ). Considering the solubility of molecular oxygen in water at room temperature $(0.27 \mathrm{mmol} / \mathrm{L})$ [43], after $15 \mathrm{~min}$ of light-exposure at $800 \mathrm{~nm}$, approximately one tenth of molecular oxygen present in solution was converted into ${ }^{1} \mathrm{O}_{2}$. 




(a)



(b)



(c)

Figure 3. Singlet oxygen generation detected by ABDA method. (a) Photobleaching of ABDA by singlet oxygen at different irradiation times $(0-15 \mathrm{~min})$ in water, and $(\mathbf{b})$ in presence of $\mathbf{1}\left(8 \cdot 10^{-5} \mathrm{M}\right)$. The experiments were carried out by using an ABDA concentration of $2 \cdot 4 \cdot 10^{-4} \mathrm{M}$ and a laser beam at $800 \mathrm{~nm}(100 \mathrm{~mW})$ as excitation source; (c) plotting of ABDA absorption at $378 \mathrm{~nm}$ as a function of the illumination time.

Table 1. Moles of ${ }^{1} \mathrm{O}_{2}$ generated after light exposure of $\mathbf{1}\left(\lambda_{\text {ex }} 800 \mathrm{~nm}-100 \mathrm{~mW}-15 \mathrm{~min}\right)$ and calculated from the amount of reacted ABDA molecules.

\begin{tabular}{cccc}
\hline Sample & $\begin{array}{c}\text { ABDA mol } \\
(\mathbf{0})\end{array}$ & $\begin{array}{c}\text { ABDA mol } \\
(\mathbf{1 5} \text { min })\end{array}$ & ${ }^{\mathbf{1}} \mathbf{O}_{\mathbf{2}}$ mol \\
\hline 1 & $7.62 \cdot 10^{-8}$ & $7.00 \cdot 10^{-8}$ & $6.2 \cdot 10^{-9}$ \\
\hline
\end{tabular}

\subsection{Two-Photon-Induced Luminescence Imaging and Calcein-AM Assay on Human} Glioblastoma Cells

To evidence the efficacy of the 2P-PDT effect, a cell experiment was conducted. In particular, the calcein-AM assay was performed on human glioblastoma U87-MG cells to determine the viability after incubation with 1 followed by two-photon excitation exposure. The acetoxymethyl derivate of calcein (calcein-AM) is a non-fluorescent hydrophobic compound that easily penetrates into viable cells. It was then converted by intracellular esterases to calcein, a strongly fluorescent compound that was retained in the cytoplasm of cells with intact membranes, producing an intense green signal (500-550 nm), whereas it was rapidly extruded from damaged or dead cells [44].

U87-MG cells were incubated with calcein-AM or with compound 1 and calcein-AM. An area of the cell medium was exposed to two-photon irradiation at $800 \mathrm{~nm}$ and the remaining region kept in the dark. Then, confocal laser scanning microscopy images were carried out detecting the luminescence signals arising from both calcein (green channel) and Ir(III) complex (red channel), by exciting the probe at $488 \mathrm{~nm}$ and 1 at $800 \mathrm{~nm}$ (Figure 4).

As clearly shown in Figure $4 \mathrm{a}-\mathrm{c}$, upon excitation at $488 \mathrm{~nm}$ a strong and intense green signal in small vesicles and in the cytoplasm was observed in U87-MG cells incubated only with calcein-AM and exposed to irradiation, indicating their viability and no toxic effects due to the NIR exposure.

In the further control experiment (Figure 4d-f)-cells were incubated with both calcein$\mathrm{AM} / \mathbf{1}$ and not exposed to radiation-the luminescence of the organometallic complex, localized mainly in the cytoplasm, was clearly visible by exciting at $800 \mathrm{~nm}$ (Figure $4 \mathrm{~d}$ ). Then, upon excitation at $488 \mathrm{~nm}$, a huge luminescence arising from the calcein probe was also detected (Figure 4e), highlighting the cell viability and consequently no citotoxicity of 1 without NIR-mediated activation. 
$800 \mathrm{~nm}$ excitation

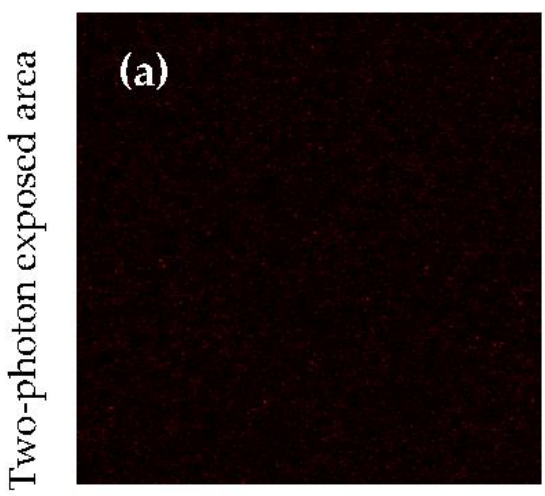

$\operatorname{Ir}(\mathrm{III})$ complex

$800 \mathrm{~nm}$ excitation
Calcein

$488 \mathrm{~nm}$ excitation
Merged channels

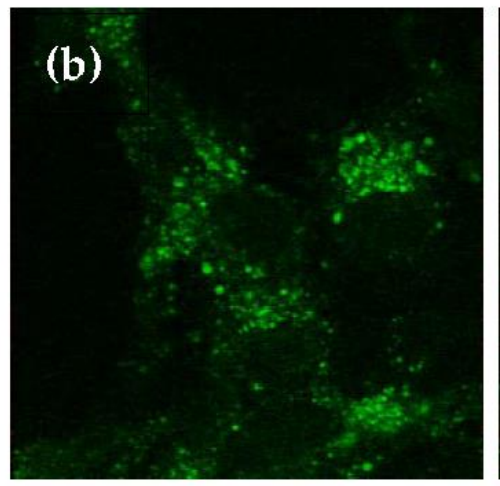

Calcein

$488 \mathrm{~nm}$ excitation

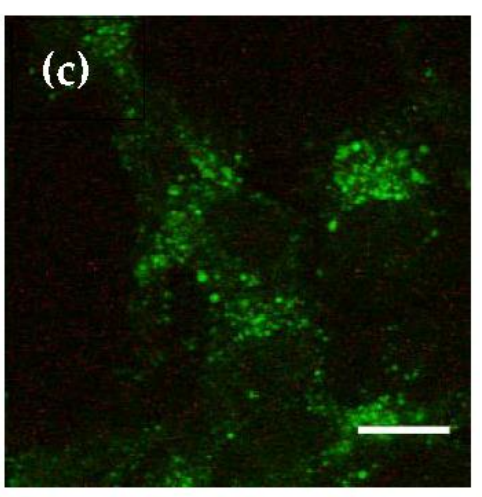

Merged channels

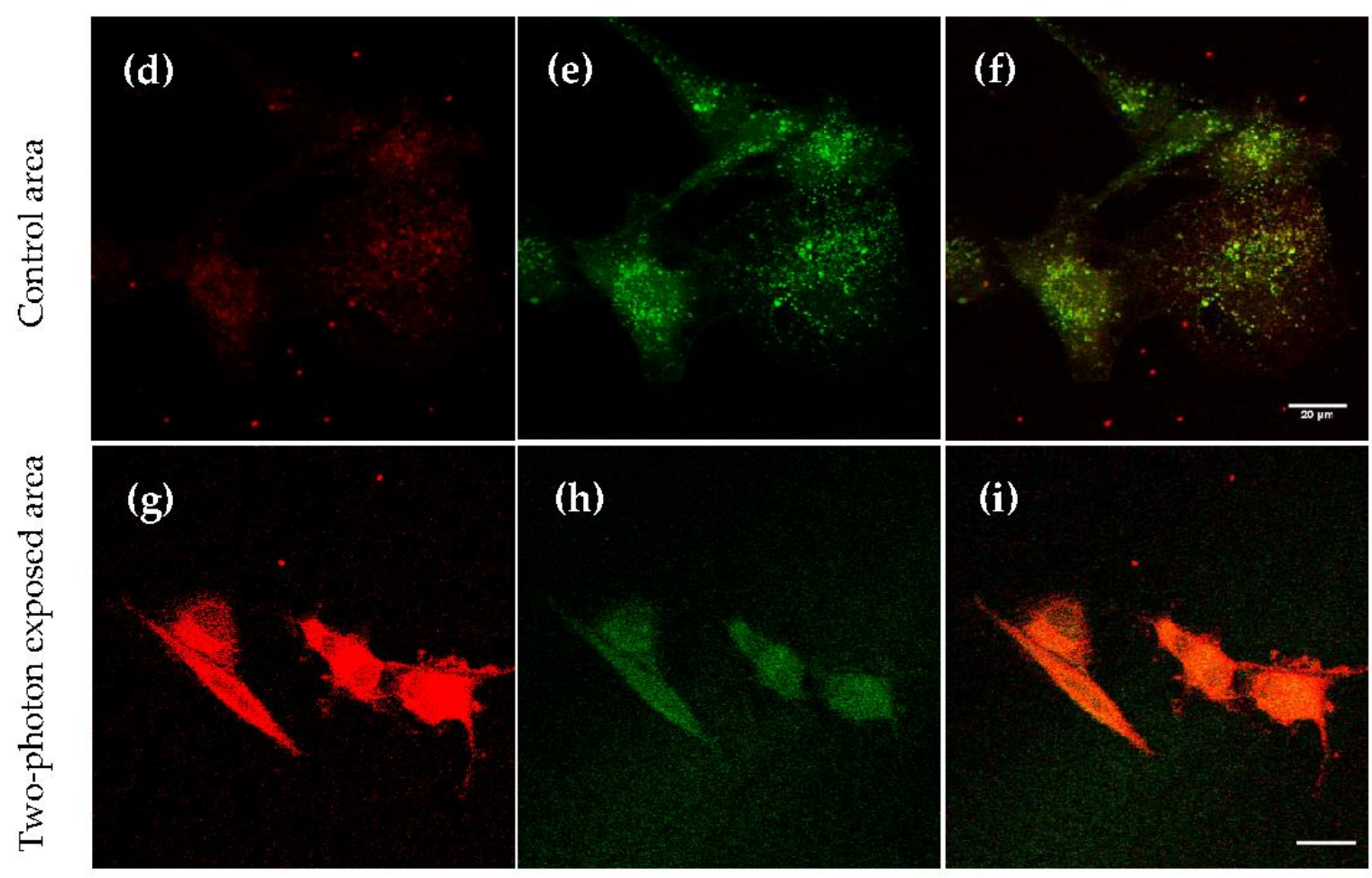

Figure 4. Representative confocal views of U87-MG cells incubated with 1 and/or calcein-AM (1, red signal, $800 \mathrm{~nm}$ excitation; calcein, green signal, $488 \mathrm{~nm}$ excitation). (a-c) Cells incubated only with calcein-AM and exposed to two-photon laser irradiation; $(\mathbf{d}-\mathbf{f})$ cells incubated with $\mathbf{1}$ and calcein-AM without two-photon laser irradiation; (g-i) cells incubated with 1 and calcein-AM and exposed to two-photon laser irradiation. Scale bar $20 \mu \mathrm{m}$.

On the contrary, in the area containing cells incubated with both calcein-AM/1 followed by NIR exposure (Figure $4 \mathrm{~g}-\mathrm{i}$ ), the green luminescence intensity of the viability marker results changed, becoming very weak and diffuse (Figure $4 \mathrm{~h}$ ), pointing out a loss of cell viability. Since no cell death was recorded in the control groups, the results confirmed that the reduced cell viability in the experimental group was clearly due to a photocytotoxic effect of the organometallic compound after two-photon irradiation. Moreover, a change in the luminescence intensity signal arising from 1 was also observed (Figure $4 \mathrm{~g}$ ). In particular-comparing the confocal view of Figure $4 \mathrm{~g}, \mathrm{~d}-\mathrm{a}$ strong increase in the emis- 
sion signal of 1 was easily observed in the area exposed to laser irradiation (Figure $4 \mathrm{~g}$ ) with respect to the unexposed one (Figure $4 \mathrm{~d}$ ). This evidence could be due to a further improvement in the solubility of $\mathbf{1}$ resulting from the local temperature increase following the laser exposure, and/or to a fast decrease in molecular oxygen concentration as a consequence of the photosensitizing activity of the $\operatorname{Ir}(\mathrm{III})$ compound. In fact, upon laser exposure, 1 generated ${ }^{1} \mathrm{O}_{2}$ and other reactive oxygen species leading plausibly to molecular oxygen depletion. As previously described, molecular oxygen leads to a strong quenching of the luminescence of $\mathbf{1}$ and its emission quantum yield is brought back to a value close to unity in hypoxic conditions.

\section{Conclusions}

Using a femtosecond $\mathrm{Ti} /$ sapphire laser as excitation source, we obtained the emission spectrum and lifetime of $\left[\operatorname{Ir}(\mathrm{ppy})_{2}(\mathrm{en})\right] \mathrm{OOCCH}_{3}(\mathbf{1})$ in aqueous solution resulting from two-photon excitation. The ${ }^{3}$ MLCT-excited state showed the same photophysical features of those obtained for a linear excitation. In addition, the two-photon system allowed the detection of a short-lived decay corresponding to the fluorescence of the compound resulting from the radiative deactivation of the ${ }^{1}$ MLCT state.

Then, the photosensitizing ability of the cyclometalated complex at the biologically relevant wavelength of $800 \mathrm{~nm}$ was evaluated using the ABDA method and the ${ }^{1} \mathrm{O}_{2}$ generation quantified.

Finally, in vitro experiments with U87-MG cells revealed that the investigated compound was able to strongly reduce the cell viability under two-photon exposure, while it had no effects on unexposed cells, highlighting its application potential as a 2P-PDT agent.

Author Contributions: Conceptualization, E.I.S. and L.R.; investigation, E.I.S., S.C., G.P., L.S. and L.R.; data curation, S.C., G.P., L.S. and L.R.; writing-original draft preparation, L.R.; writingreview and editing, M.L.D. and G.S. All authors have read and agreed to the published version of the manuscript.

Funding: This research was funded by Romanian Ministry of Education and Research, CNCSUEFISCDI, project number PN-III-P4-ID-PCE-2020-1958, within PNCDI III.

Institutional Review Board Statement: Not applicable.

Informed Consent Statement: Not applicable.

Data Availability Statement: Proper links are provided in the manuscripts therefore this statement can be excluded.

Acknowledgments: E.I.S. acknowledges the Romanian Academy, Program 4.

Conflicts of Interest: The authors declare no conflict of interest. The funders had no role in the design of the study; in the collection, analyses or interpretation of data; in the writing of the manuscript; or in the decision to publish the results.

\section{References}

1. Brown, S.B.; Brown, E.A.; Walker, I. The Present and Future Role of Photodynamic Therapy in Cancer Treatment. Lancet Oncol. 2004, 5, 497-508. [CrossRef]

2. Choi, Y.M.; Adelzadeh, L.; Wu, J.J. Photodynamic Therapy for Psoriasis. J. Dermatolog. Treat. 2015, 26, 202-207. [CrossRef]

3. Zhang, P.A. Clinical Review of Phototherapy for Psoriasis. Lasers Med. Sci. 2018, 33, 173-180. [CrossRef]

4. Cruess, A.F.; Zlateva, G.; Pleil, A.M.; Wirostko, B. Photodynamic Therapy with Verteporfin in Age-related Macular Degeneration: A Systematic Review of Efficacy, Safety, Treatment Modifications and Pharmacoeconomic Properties. Acta Ophthalmol. 2009, 87, 118-132. [CrossRef]

5. Lotufo, M.A.; Tempestini Horliana, A.C.R.; Santana, T.; de Queiroz, A.C.; Gomes, A.O.; Motta, L.J.; Ferrari, R.A.M.; dos Santos Fernandes, K.P.; Bussadori, S.K. Efficacy of Photodynamic Therapy on the Treatment of Herpes Labialis: A Systematic Review. Photodiagn. Photodyn. Ther. 2020, 29, 101536. [CrossRef]

6. Conrado, P.C.V.; Sakita, K.M.; Arita, G.S.; Galinari, C.B.; Gonçalves, R.S.; Lopes, L.D.G.; Lonardoni, M.V.C.; Teixeira, J.J.V.; Bonfim-Mendonça, P.S.; Kioshima, E.S. A Systematic Review of Photodynamic Therapy as an Antiviral Treatment: Potential Guidance for Dealing with SARS-CoV-2. Photodiagn. Photodyn. Ther. 2021, 34, 102221. [CrossRef] [PubMed] 
7. Shen, J.J.; Jemec, G.B.E.; Arendrup, M.C.; Saunte, D.M.L. Photodynamic Therapy Treatment of Superficial Fungal Infections: A Systematic Review. Photodiagn. Photodyn. Ther. 2020, 31, 101774. [CrossRef] [PubMed]

8. Castano, A.P.; Demidova, T.N.; Hamblin, M.R. Mechanisms in Photodynamic Therapy: Part One-Photosensitizers, Photochemistry and Cellular Localization. Photodiagn. Photodyn. Ther. 2004, 1, 279-293. [CrossRef]

9. Lovell, J.F.; Liu, T.W.B.; Chen, J.; Zheng, G. Activatable Photosensitizers for Imaging and Therapy. Chem. Rev. 2010, 110, $2839-2857$. [CrossRef]

10. Fan, W.; Huang, P.; Chen, X. Overcoming the Achilles' Heel of Photodynamic Therapy. Chem. Soc. Rev. 2016, 45, 6488-6519. [CrossRef]

11. Bolze, F.; Jenni, S.; Sour, A.; Heitz, V. Molecular Photosensitisers for Two-Photon Photodynamic Therapy. Chem. Commun. 2017, 53, 12857-12877. [CrossRef] [PubMed]

12. Sun, Z.; Zhang, L.-P.; Wu, F.; Zhao, Y. Photosensitizers for Two-Photon Excited Photodynamic Therapy. Adv. Funct. Mater. 2017, 27, 1704079. [CrossRef]

13. Ogawa, K.; Kobuke, Y. Recent Advances in Two-Photon Photodynamic Therapy. Anti-Cancer Agents Med. Chem. 2008, 8, 269-279. [CrossRef]

14. Pawlicki, M.; Collins, H.A.; Denning, R.G.; Anderson, H.L. Two-Photon Absorption and the Design of Two-Photon Dyes. Angew. Chem. Int. Ed. 2009, 48, 3244-3266. [CrossRef]

15. Collins, H.A.; Khurana, M.; Moriyama, E.H.; Mariampillai, A.; Dahlstedt, E.; Balaz, M.; Kuimova, M.K.; Drobizhev, M.; Yang, V.X.D.; Phillips, D.; et al. Blood-Vessel Closure Using Photosensitizers Engineered for Two-Photon Excitation. Nature Photon. 2008, 2, 420-424. [CrossRef]

16. Tan, C.-P.; Zhong, Y.-M.; Ji, L.-N.; Mao, Z.-W. Phosphorescent Metal Complexes as Theranostic Anticancer Agents: Combining Imaging and Therapy in a Single Molecule. Chem. Sci. 2021, 12, 2357-2367. [CrossRef] [PubMed]

17. Chen, Y.; Guan, R.; Zhang, C.; Huang, J.; Ji, L.; Chao, H. Two-Photon Luminescent Metal Complexes for Bioimaging and Cancer Phototherapy. Coord. Chem. Rev. 2016, 310, 16-40. [CrossRef]

18. McKenzie, L.K.; Bryant, H.E.; Weinstein, J.A. Transition Metal Complexes as Photosensitisers in One- and Two-Photon Photodynamic Therapy. Coord. Chem. Rev. 2019, 379, 2-29. [CrossRef]

19. Cho, J.-Y.; Barlow, S.; Marder, S.R.; Fu, J.; Padilha, L.A.; Van Stryland, E.W.; Hagan, D.J.; Bishop, M. Strong Two-Photon Absorption at Telecommunications Wavelengths in Nickel Bis (Dithiolene) Complexes. Opt. Lett. 2007, 32, 671-673. [CrossRef] [PubMed]

20. He, G.S.; Tan, L.-S.; Zheng, Q.; Prasad, P.N. Multiphoton Absorbing Materials: Molecular Designs, Characterizations, and Applications. Chem. Rev. 2008, 108, 1245-1330. [CrossRef]

21. Castellano, F.N.; Malak, H.; Gryczynski, I.; Lakowicz, J.R. Creation of Metal-to-Ligand Charge Transfer Excited States with Two-Photon Excitation. Inorg. Chem. 1997, 36, 5548-5551. [CrossRef]

22. Edkins, R.M.; Bettington, S.L.; Goeta, A.E.; Beeby, A. Two-Photon Spectroscopy of Cyclometalated Iridium Complexes. Dalton Trans. 2011, 40, 12765-12770. [CrossRef]

23. Boca, S.C.; Astilean, S.; Baldeck, P.L.; Lemercier, G. An Ethylene-Glycol Decorated Ruthenium(II) Complex for Two-Photon Photodynamic therapy. Chem. Commun. 2009, 30, 4590-4592. [CrossRef]

24. Cho, S.; You, Y.; Nam, W. Lysosome-Specific One-Photon Fluorescence Staining and Two-Photon Singlet Oxygen Generation by Molecular Dyad. RSC Adv. 2014, 4, 16913-16916. [CrossRef]

25. Zamora, A.; Vigueras, G.; Rodríguez, V.; Santana, M.D.; Ruiz, J. Cyclometalated Iridium(III) Luminescent Complexes in Therapy and Phototherapy. Coord. Chem. Rev. 2018, 360, 34-76. [CrossRef]

26. Boreham, E.M.; Jones, L.; Swinburne, A.N.; Blanchard-Desce, M.; Hugues, V.; Terryn, C.; Miomandre, F.; Lemercier, G.; Natrajan, L.S. A Cyclometallated Fluorenyl Ir(III) Complex as a Potential Sensitiser for Two-Photon Excited Photodynamic Therapy (2PE-PDT). Dalton Trans. 2015, 44, 16127-16135. [CrossRef] [PubMed]

27. Bi, X.-D.; Yang, R.; Zhou, Y.-C.; Chen, D.; Li, G.-K.; Guo, Y.-X.; Wang, M.-F.; Liu, D.; Gao, F. Cyclometalated Iridium(III) Complexes as High-Sensitivity Two-Photon Excited Mitochondria Dyes and Near-Infrared Photodynamic Therapy Agents. Inorg. Chem. 2020, 59, 14920-14931. [CrossRef] [PubMed]

28. Qiu, K.; Huang, H.; Liu, B.; Liu, Y.; Huang, Z.; Chen, Y.; Ji, L.; Chao, H. Long-Term Lysosomes Tracking with a Water-Soluble Two-Photon Phosphorescent Iridium(III) Complex. ACS Appl. Mater. Interfaces 2016, 8, 12702-12710. [CrossRef]

29. Karges, J.; Kuang, S.; Maschietto, F.; Blacque, O.; Ciofini, I.; Chao, H.; Gasser, G. Rationally Designed Ruthenium Complexes for 1and 2-Photon Photodynamic Therapy. Nat. Commun. 2020, 11, 3262. [CrossRef]

30. Huang, H.; Yu, B.; Zhang, P.; Huang, J.; Chen, Y.; Gasser, G.; Ji, L.; Chao, H. Highly Charged Ruthenium(II) Polypyridyl Complexes as Lysosome-Localized Photosensitizers for Two-Photon Photodynamic Therapy. Angew. Chem. Int. Ed. 2015, 54, 14049-14052. [CrossRef] [PubMed]

31. Hess, J.; Huang, H.; Kaiser, A.; Pierroz, V.; Blacque, O.; Chao, H.; Gasser, G. Evaluation of the Medicinal Potential of Two Ruthenium(II) Polypyridine Complexes as One- and Two-Photon Photodynamic Therapy Photosensitizers. Chem. Eur. J. 2017, 23, 9888-9896. [CrossRef] [PubMed]

32. Heinemann, F.; Karges, J.; Gasser, G. Critical Overview of the Use of Ru(II) Polypyridyl Complexes as Photosensitizers in One-Photon and Two-Photon Photodynamic Therapy. Acc. Chem. Res. 2017, 50, 2727-2736. [CrossRef] [PubMed]

33. Ricciardi, L.; Mastropietro, T.F.; Ghedini, M.; La Deda, M.; Szerb, E.I. Ionic-Pair Effect on the Phosphorescence of Ionic Iridium(III) Complexes. J. Organomet. Chem. 2014, 772, 307-313. [CrossRef] 
34. Ricciardi, L.; Sancey, L.; Palermo, G.; Termine, R.; De Luca, A.; Szerb, E.I.; Aiello, I.; Ghedini, M.; Strangi, G.; La Deda, M. Plasmon-Mediated Cancer Phototherapy: The Combined Effect of Thermal and Photodynamic Processes. Nanoscale 2017, 9, 19279-19289. [CrossRef] [PubMed]

35. Ricciardi, L.; Chatterjee, S.; Palermo, G.; Szerb, E.I.; Sanna, A.; Palermo, F.; Pieroni, N.; Fratini, M.; Bartolino, R.; Cedola, A.; et al. Glioblastoma Treatments with Photo-Nanotherapeutics Induce Massive Devascularization and Tumor Elimination. arXiv 2021, $2101,05152$.

36. Makarov, N.S.; Drobizhev, M.; Rebane, A. Two-Photon Absorption Standards in the 550-1600 nm Excitation Wavelength Range. Opt. Express 2008, 16, 4029-4047. [CrossRef] [PubMed]

37. Krajczewski, J.; Rucińska, K.; Townley, H.E.; Kudelski, A. Role of Various Nanoparticles in Photodynamic Therapy and Detection Methods of Singlet Oxygen. Photodiagn. Photodyn. Ther. 2019, 26, 162-178. [CrossRef] [PubMed]

38. Koide, Y.; Takahashi, S.; Vacha, M. Simultaneous Two-Photon Excited Fluorescence and One-Photon Excited Phosphorescence from Single Molecules of an Organometallic Complex Ir(Ppy) ${ }_{3}$. J. Am. Chem. Soc. 2006, 128, 10990-10991. [CrossRef] [PubMed]

39. Furuta, T.; Wang, S.S.-H.; Dantzker, J.L.; Dore, T.M.; Bybee, W.J.; Callaway, E.M.; Denk, W.; Tsien, R.Y. Brominated 7Hydroxycoumarin-4-Ylmethyls: Photolabile Protecting Groups with Biologically Useful Cross-Sections for Two Photon Photolysis. Proc. Natl. Acad. Sci. USA 1999, 96, 1193-1200. [CrossRef]

40. Ishi-i, T.; Taguri, Y.; Kato, S.; Shigeiwa, M.; Gorohmaru, H.; Maeda, S.; Mataka, S. Singlet Oxygen Generation by Two-Photon Excitation of Porphyrin Derivatives Having Two-Photon-Absorbing Benzothiadiazole Chromophores. J. Mater. Chem. 2007, 17, 3341-3346. [CrossRef]

41. Tian, X.; Zhu, Y.; Zhang, M.; Luo, L.; Wu, J.; Zhou, H.; Guan, L.; Battaglia, G.; Tian, Y. Localization Matters: A Nuclear Targeting Two-Photon Absorption Iridium Complex in Photodynamic Therapy. Chem. Commun. 2017, 53, 3303-3306. [CrossRef] [PubMed]

42. Entradas, T.; Waldron, S.; Volk, M. The Detection Sensitivity of Commonly Used Singlet Oxygen Probes in Aqueous Environments. J. Photochem. Photobiol. B: Biol. 2020, 204, 111787. [CrossRef] [PubMed]

43. Montalti, M.; Credi, A.; Prodi, L.; Gandolfi, M.T. Handbook of Photochemistry; CRC Press: Boca Raton, FL, USA, 2006; ISBN 978-0-429-11538-7.

44. Bratosin, D.; Mitrofan, L.; Palii, C.; Estaquier, J.; Montreuil, J. Novel Fluorescence Assay Using Calcein-AM for the Determination of Human Erythrocyte Viability and Aging. Cytometry 2005, 66A, 78-84. [CrossRef] [PubMed] 